原

著

\title{
特発性の心室性期外収縮の運動負荷試験における変 化：運動後低カリウム血症の重要性
}

\author{
中須賀一太 ${ }^{* 1}$ 岡本和彦*1 久保田聡子*1 有田武史*1 \\ 古賀英幸*1 安田雄一郎*1 林田晃寛*1 山形康洋*1 \\ 久間文明*1 伊東裕幸*1 丸山 徹*2 加治良一*1 \\ 金谷庄藏*3 藤野武彦*2 原田実根*1, 2
}

【目的】右室流出路起源の心室性期外収縮 (PVC) は運動誘発性を特徵のひとつとする がその詳細は報告によって若干異なるため，今回運動負荷試験中のPVCを血漿力 テコールアミン濃度および血清 $\mathrm{K}+$ 濃度との関連で検討した.【方法】体表面心電図 波形から右室流出路起源と判断されたPVCを有する 3 症例に症候限界性の運動負 荷試験を施行した．連続心電図記録下のPVCの発生頻度と血漿カテコールアミン 濃度と血清 $K+$ 濃度との関連を検討した.【結果】運動負荷試験の進行につれて PVC は増加傾向を示し, 血漿カテコールアミン濃度と血清 $\mathrm{K}+$ 濃度は直線的に増加した. しかし最大運動強度に近づくにつれてPVCは減少ないし消失し, 血清K+濃度の増 加は血漿カテコールアミン濃度のそれに比して鈍化した．運動終了後は血漿カテコー ルアミン濃度と血清 $K+$ 濃度は急速に減少したが, 血清 $K+$ 濃度の低下が顕著であつ た (postexercise hypokalemia)，血漿カテコールアミン濃度が運動前值にまで低下 せずに低 $K^{+}$血症を示す運動直後の数分間にPVCが頻発した.【結語】右室流出路起 源のPVCの運動誘発性を検討する際は，血漿カテコールアミン濃度のみならず血 清K+濃度を考慮する必要性が示唆された。（心電図, $2002 ; 22$ : 242～249)

\begin{tabular}{|ll|}
\hline Keywords & ・運動 \\
& $\bullet$ カリウム \\
& • 心室性期外収縮 \\
& ・交感神経 \\
\hline
\end{tabular}

* 1 九州大学大学院医学研究院病態修復内科学講座

（テ812-8582 福岡市東区馬出3-1-1）

*2 九州大学健康科学センター

*3 佐世保共済病院内科

\section{I.はじめに}

右室流出路起源の心室性期外収縮 (PVC) は臨床的 に比較的よくみられ, 従来予後は比較的良好とされ ていたが，近年必ずしもそうではないとする報告も みられる ${ }^{1)}$. 事実以前から右室流出路起源のPVCを 有する症例での失神 ${ }^{2,}{ }^{3)}$ や突然死 ${ }^{4), 5)}$, 薬物療法無効

Idiopathic premature ventricular contractions during exercise: importance of postexercise hypokalemia Kazuta Nakasuga, Kazuhiko Okamoto, Satoko Kubota, Takeshi Arita, Hideyuki Koga, Yuichirou Yasuda, Akihiro Hayashida, Yasuhiro Yamagata, Fumiaki Kuma, Hiroyuki Ito, Toru Maruyama, Yoshikazu Kaji, Shozo Kanaya, Takehiko Fujino, Mine Harada 
の際の手術例 ${ }^{2)}$ な゙が散発的に報告されてきた. 右 室流出路起源のPVCの発生機序は, 異所性自動能や 撃発活動などの非リエントリー性の機序であるとす る見解が多(6)，7).このことと関連して右室流出路 起源のPVCは, 運動誘発性も特徴のひとつとされて いる ${ }^{8)}$. 運動は交感神経を賦活化し, その前後でカ リウム $\left(\mathrm{K}^{+}\right)$を始めとする血清電解質濃度が大きく 変動する.

以前に我々は健常若年者の運動負荷試験前後の血 行動態と血液生化学データとの対応を解析し ${ }^{9) \sim 11)}$, またこれとは別に観血的な電気生理学的検査にて右 室流出路起源と同定されたPVCの発生状況を, ホル

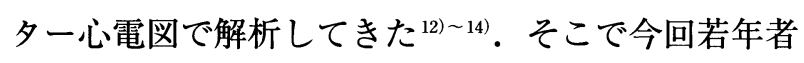
のケーススタディとして, 無症候性かつ標準 12 誘導 心電図で右室流出路起源と判断された特発性のPVC の運動負荷試験中の発生動態を, 血漿カテコールア ミン濃度および血清 $\mathrm{K}+$ 濃度との関連で検討した。

\section{II. 対}

本学で毎年行う学生定期健康診断は対象者全員の 標準 12 誘導心電図を記録し，期外収縮や房室ブロッ クなどの不整脈を指摘された場合には心エコー検査 (東芝SSH-140A) とホルター心電図検査 (フクダ電子 SM-29)を実施している. 対象はこの定期健康診断に てPVCを指摘された 3 名である. 対象の平均年齢は $21.3 \pm 1.4$ 歳で全員男子学生であり, 特に服薬はなかっ た. また正規の授業での体育の履修以外に課外活動 としての運動歴はなかった.

\section{III. 方法}

この3名の本学学生において文書同意のもとに症 候限界性の運動負荷試験を試行した，運動負荷試験 中は標準 12 誘導心電図をモニターし, 毎分間接法で 上腕での血圧を測定した. また経時的に前腕静脈か ら採血を行い, 血漿カテコールアミン濃度と血清 $\mathrm{K}^{+}$濃度を測定した。症候限界性の運動負荷試験は エルゴメーターを使用した。運動強度は 4 分ごとに 段階的に $25 \mathrm{watt}$ ずつ増強し, 最終運動強度は 100watt となるよう，4段階で 16 分間行った.

\section{IV. 結 果}

対象のうち 1 名の学生の標準 12 誘導心電図を図 $1 \mathrm{~A}$ に示す。単発性のPVCのQRS 波形は，肢誘導か らは II， III， $\mathrm{aV}_{\mathrm{F}}$ 誘導で高い $\mathrm{R}$ 波を示す下方軸であ り，胸部誘導では左脚ブロック型であった。 また同 日試行した心エコー検査では僧帽弁逸脱症を含めて 明らかな異常所見はみられず，左心機能も正常域で あった。以上より今回対象とした 3 名は特発性の右 室流出路起源のPVCと判断した.

\section{1. 運動前後の心拍数と血圧值}

3 名とも運動負荷試験開始後, 心拍数と収縮期血 圧は生理的に漸時増加し, 目標心拍数 (180 $190 \mathrm{bpm})$ に到達して終了した. 拡張期血圧は運動中 に不変ないしやや低下する傾向がみられた，運動負 荷試験中, 胸部症状その他の自覚症状の出現はなかっ た. 負荷試験終了直後に迷走神経反射にて気分不良 となった学生は1名いたが, 飲水と休㕷のみで回復 した. 回復期には収縮期血圧と心拍数はともに 5 分 程度で運動開始前のレベルに復した。

\section{2. 運動前後の心室性不整脈}

代表的な運動負荷試験中のPVCの発生状況を図 1Bに示す．運動負荷試験はまず卧位で心電計を装 着した. 開始前は坐位で検查の説明を聞くことによ る緊張のためか, PVCは比較的よく観察された。運 動負荷試験が開始されて運動強度が増加すると心拍 数の増加に伴って, PVCの発生頻度は増加する傾向 にあった。しかし運動強度が最大となって目標心拍 数に近づくと, PVCは減少傾向となり終了直前には まったくみられなくなった.さらに運動負荷終了後 には再びPVCが頻発してその頻度は運動負荷試験前 を凌駕した．以上の運動負荷試験前後でのPVCの発 生状況は3名とも同様であった(図2の下段).

\section{3. 運動前後の血清 $\mathrm{K}^{+}$濃度}

運動開始時点から運動強度が増すにしたがって血 清 $\mathrm{K}^{+}$濃度も漸時上昇した。最大運動強度において は血清 $\mathrm{K}+$ 濃度も最大值に達し, その平均値は 
A

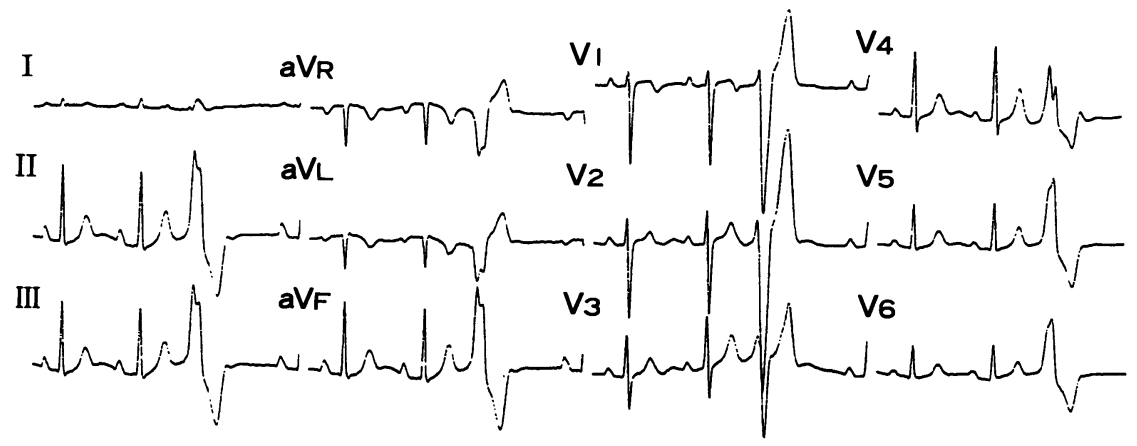

B rest

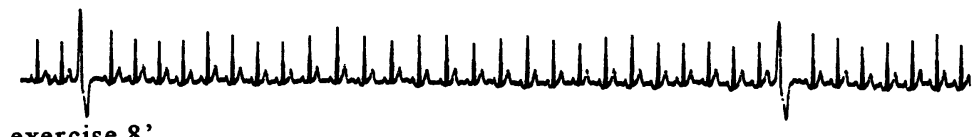

exercise 8

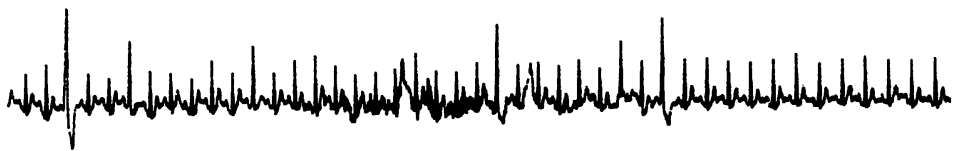

exercise $16^{\prime}$

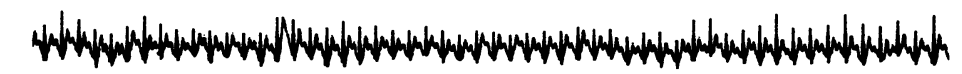

postexercise 4'

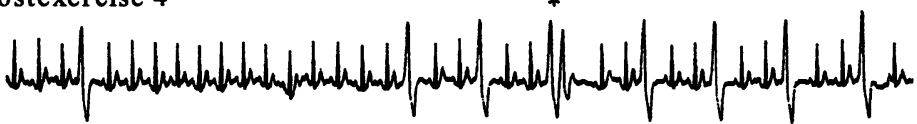

postexercise $6^{\prime}$

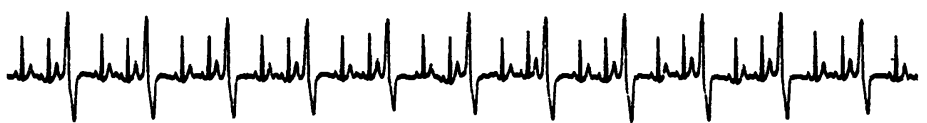

図1 特発性の心室性期外収縮 (PVC) を有する学生の安静時の標準 12 誘導心 電図 (A) と運動負荷心電図 (B)

運動負荷前および開始後に散発していたPVCが終了直前には消失した。また運動負荷試験 終了後にPVCは頻発し，終了 4 分後には二連発 $\left(^{*}\right), 6$ 分後には三段脈になっていることに 注意.

$5.44 \pm 0.45 \mathrm{mEq} / \mathrm{L}$ であった．運動負荷試験終了後数 分間は cooling downのための軽い運動を施している にもかかわらず，血清 $\mathrm{K}+$ 濃度は急速に低下して運 動終了 3〜 5分にかけて最低值 $(3.38 \pm 0.43 \mathrm{mEq} / \mathrm{L})$ を示した後, 緩やかに前值に復した(図2).

4. 運動前後の血漿カテコールアミン濃度

血漿カテコールアミンはエピネフリン，ノルエピ ネフリンともに運動開始から漸時上昇し, 運動終了 直前に最大值を示した。運動終了後は急速に低下し たが，回復期においても完全には運動前値に復しな
かった(図2).また対象とした 3 例について血槳ノ ルエピネフリン濃度に対する血清 $\mathrm{K}+$ 濃度の運動前 後での変化を図3に示す. 運動開始後しばらくは血 清 $\mathrm{K}+$ 濃度は血漿ノルエピネフリン濃度に対して良 好な正の相関を示して増加し, その回帰直線は $\mathrm{y}=$ $0.363 \times 10^{-3} \cdot \mathrm{x}+4.120(\mathrm{r}=0.928)$ となった. しかし 運動強度が増して目標心拍数近くになるにしたがい その相関は回帰直線から次第に外れ, 血漿ノルエピ ネフリン濃度の増加に比して相対的に血清 $\mathrm{K}^{+}$濃度 の増加は鈍化した．運動終了後は運動中の両者の正 JPN. J. ELECTROCARDIOLOGY Vol. 22 No. 42002 
の相関関係から大きく外れてヒステリーシスを示

し，血清 $\mathrm{K}+$ 濃度の減少は相対的に血漿ノルエピネ

V. 考 案

フリン濃度の減少より顕著であった(図3).

器質的心疾患を有しない若年者にみられるPVCの 多くは右室流出路起源でその予後は比較的良好とさ れる. しかし以前の我々の検討では運動負荷試験で

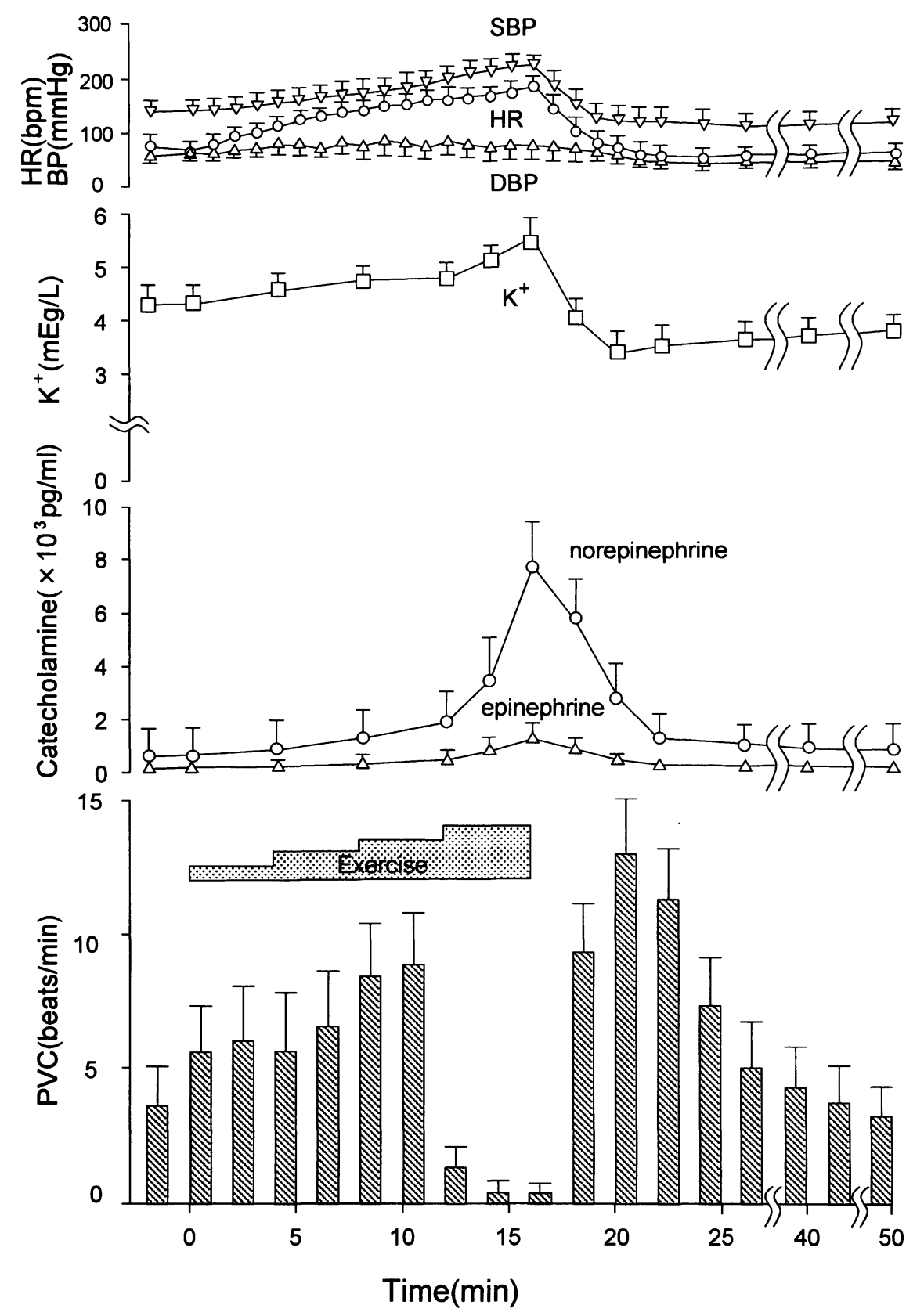

図2 特発性のPVC を有する3例の運動負荷試験の結果 (mean $\pm S D)$

時間軸は運動負荷試験開始時点を 0 とした. DBP：拡張期血圧, HR：心拍数, SBP : 収縮 期血圧 


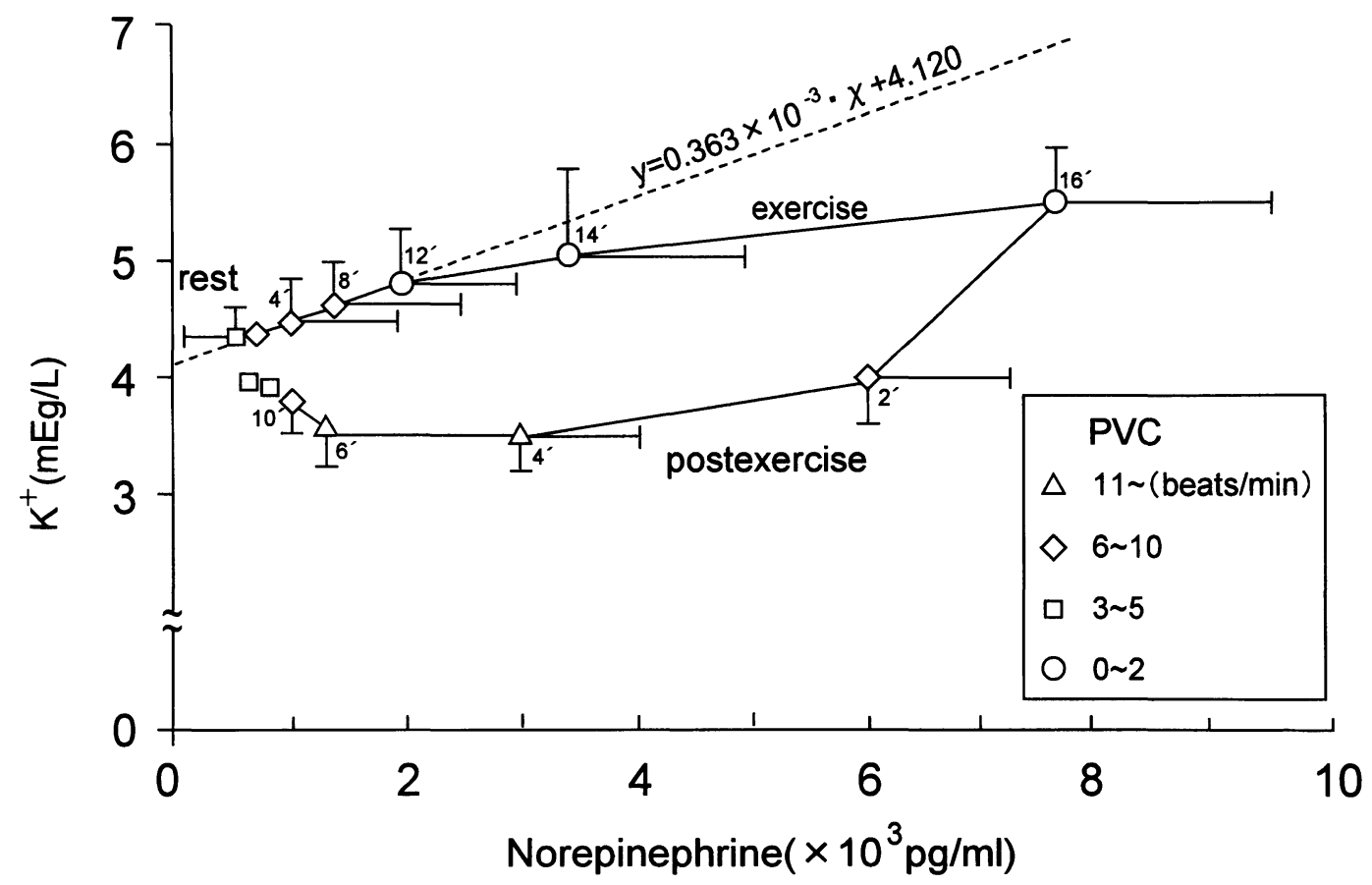

図3血漿ノルエピネフリン濃度に対する血清 $K^{+}$濃度の運動前後での変化 (mean $\left.\pm S D\right)$ と PVCの頻度

両者の運動中の増加過程と終了後の減少過程がヒステリーシスを示し, 運動負荷試験終了直後に血清 $\mathrm{K}^{+}$ 濃度が大きく低下する (postexercise hypokalemia)ことに注意.

PVCが頻発, 連発する学生ほど間接法でみた最大酸 素摄取量が低い傾向にあった ${ }^{15)}$.また最近右室流出 路起源のPVCを有する若年女性で，瘦身用に甘草を 含有したお茶を長期飲用し，低 $\mathrm{K}^{+}$血症 $(2.7 \mathrm{mEq} / \mathrm{L})$ の状態で運動直後に心室細動を発生した救命例を経 験した ${ }^{16)}$. さらに近年無症候性に頻発するPVCを有 する症例の長期予後は必ずしも良好ではないとする 報告もみられる ${ }^{11}$. 以上のような背景をもとに今回 の検討を行った。

\section{PVCの運動前後での発生状況}

今回の検討の対象者は観血的な電気生理学的検討 は行っていないものの, 標準 12 誘導心電図で下方軸 および左脚ブロック型であることより(図 1A)，そ の発生起源は右室流出路と考えて差し支えないと判 断された ${ }^{17)}$ 。このようなPVCは運動誘発性を特徴と するが, 今回の対象者も運動負荷試験前後でのPVC の発生状況に共通した特徴があった.すなわち運動
強度が増加すると心拍数の増加に伴いPVCの発生頻 度は増加したが, 運動強度が最大に近づくと減少し 最大強度ではほとんどみられなくなった。 さらに運 動負荷終了後に再びPVCが頻発して, その頻度は運 動負荷試験前を凌駕した.このような運動負荷試験 でのPVCの特徴は以前に同様の検討を行った時にも 確認され ${ }^{15)}$ ，またHoltらの報告にも一致する ${ }^{2)}$.

PVCの発生頻度に心拍数依存性があることは当初 Winkleにより提唱されたが18), ItoらはPVCと心拍 数の相関を正相関とそれ以外の型に分類し，さらに Ca拮抗剤や $\beta$ ブロッカーの内服による介入を試みる ことにより, PVCの発生機序がホルター心電図から 非観血的に推定されることを提唱した ${ }^{19)}$, 20). Itoら は運動負荷試験ではなくホルター心電図のモニタリ ング中の心拍数とPVCの相関を解析しており，その 最大心拍数は $110 \mathrm{bpm}$ 前後である. 今回この範囲の 心拍数ではいずれの例でも運動中のPVCは増加した 
(図2).その意味で今回のPVCと心拍数の関係は, Itoらの分類に従えば正相関を示すといえる. 正相関 を示すPVCは撃発活動に起因するとされているが20), これは右室流出路起源のPVCが非リエントリー性と される点に矛盾しない( ${ }^{6)}$, .

2. 運動前後での血漿カテコールアミンと血清 $\mathrm{K}^{+}$ 濃度

今回の検討では運動負荷試験中, 交感神経の活性 化の指標とされる血嶈カテコールアミン濃度に対し て血清 $\mathrm{K}^{+}$濃度が正の相関を示した(図3)。このよう に血漿カテコールアミン濃度と血清 $\mathrm{K}^{+}$濃度の間に は密接な関係が認められる ${ }^{21)}$. 全身の骨格筋は運動 強度に応じて循環血液中に $\mathrm{K}^{+}$を放出するが, 循環 血中の $\mathrm{K}^{+}$を取り込むうえでの生体で最大のリザー バーでもある，その $\mathrm{K}^{+}$の取り込みは交感神経系で制 御された $\mathrm{Na}^{+}-\mathrm{K}^{+}$ポンプによってなされている22) 24). すなわち骨格筋細胞の表面膜に存在する $\mathrm{Na}^{+}-\mathrm{K}^{+}$ポ ンプが交感神経の $\beta$ 刺激で活性化されると, 骨格筋 への $\mathrm{K}^{+}$の取り込みによって血清 $\mathrm{K}^{+}$濃度は低下する ${ }^{25}$. 実際Williams らは $\beta$ 遮断剂を前投与することにより 運動直後の低 $\mathrm{K}^{+}$血症 (postexercise hypokalemia)が 軽減することを確認した ${ }^{24)}$.

今回の検討では運動開始後しばらくは両者は良好 な正相関を示したが運動強度が増すにつれて相対的 に血清 $\mathrm{K}^{+}$濃度の増加が鈍化した. これは運動開始後 カテコールアミンの増加で活性化され始めた $\mathrm{Na}^{+}-\mathrm{K}^{+}$ ポンプによる骨格筋への $\mathrm{K}^{+}$の取り込みによる可能 性が示唆される.また運動終了直前に最大值を示し た血漿カテコールアミンと血清 $\mathrm{K}^{+}$濃度は, ともに 運動終了後数分以内に急速に低下した (図2). しか しこの時血清 $\mathrm{K}+$ 濃度は相対的に血漿カテコールア ミン濃度より顕著な減少を示し(図3), 運動終了数 分後の血清 $\mathrm{K}+$ 濃度は運動前值より低かった (postexercise hypokalemia) ${ }^{25)}$. このような現象は以 前にも我々は確認したが9), 運動による交感神経の 活性化が骨格筋の $\mathrm{Na}^{+}-\mathrm{K}^{+}$ポンプを若干の潜時をもっ て活性化し, このポンプの活性化は運動終了後もし ばらく持続することによると推測される ${ }^{26)}$.

\section{3. 撃発活動とカテコールアミンおよび $K^{+}$濃度}

Itoらの分類では心拍数に対して正相関を示す PVCは，遅延後脱分極に基づく撃発活動をその発生 原因とすると考えられている ${ }^{19), 20)}$. この遅延後脱分 極の細胞電気生理学的な背景は心筋細胞内の $\mathrm{Ca}^{2+} の$ 過負荷状態であるが, 細胞外の $\mathrm{K}^{+}$濃度も重要であ る.これは細胞外の $\mathrm{K}^{+}$濃度が静止時の細胞膜のコ ンダクタンスに大きく影響するためである ${ }^{27)}$. 遅延 後脱分極の原因となる一過性内向き電流が一定量流 入した場合，高 $\mathrm{K}^{+}$血症(背景コンダクタンスが高い 状態)では遅延後脱分極の振幅は小さくなり，これ が活動電位発生の間值に到達する可能性は低くな る. 実際 $\mathrm{K}$ チャネルオープナーであるニコランジル

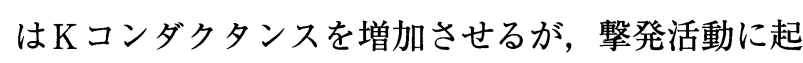
因する特発性心室頻拍を抑制することが報告されて いる ${ }^{28)}$.これに対して低 $\mathrm{K}^{+}$血症(背景コンダクタン スが低い状態)では，同じ電流量の一過性内向き電 流が流入すると遅延後脱分極の振幅が大きくなって 発火間值に達する可能性は高くなる，さらに著しい 低 $\mathrm{K}^{+}$血症では $\mathrm{Na}^{+}-\mathrm{K}^{+}$ポンプ自体も抑制されて，心 筋細胞内の $\mathrm{Ca}^{2+}$ 過負荷が促進される ${ }^{29)}$.

今回の運動負荷試験前後のPVCの発生動態は推測 の域を出ないが以下のように説明される. 運動によ り増加した血漿カテコールアミンは $\beta$ 作用によって 心筋細胞内の $\mathrm{cAMP}$ 濃度と $\mathrm{Ca}^{2+}$ 流入量の増加をもた らす．これは遅延後脱分極の発生には必須の条件で あるが, 運動強度が最大に近くなった際の高 $\mathrm{K}^{+}$血 症は上記の理由で遅延後脱分極を抑制する，運動終 了直後は残存する心筋細胞内の $\mathrm{Ca}^{2+}$ 過負荷と運動直 後の低 $\mathrm{K}^{+}$血症の影響で遅延後脱分極は最も発生し やすい状態となり, 撃発活動に起因するPVCが頻発 することになる.

従来運動誘発性が指摘されていたもののその詳細 は不明であった右室流出路起源のPVCは, 血漿カテ コールアミン濃度のみならず血清 $\mathrm{K}^{+}$濃度もあわせ て検討し, 細胞レベルでの遅延後脱分極の発生機序 を考慮することで上記のように運動との関連性を統 一的に説明できるものと考えられる.しかし運動に 
より変化し，遅延後脱分極にも影響を及ほす生理的

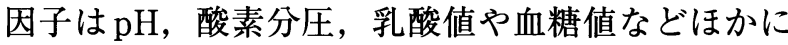
も多数あり ${ }^{30)}$ ，これらも含めた総合的な評価が必要 である.また本研究は症例研究の域を出ず，PVCの ない対照群の設定か，今回の症例に $\beta$ 遮断剂を投与 した状態で運動負荷試験を行う比較研究が今後必要 であろう。 $\beta$ 遮断剤の心臟突然死の予防効果はいく つかの大規模臨床試験で周知のところである ${ }^{31) ~ 34) . ~}$ これは $\beta$ 遮断作用による $\mathrm{cAMP}$ 濃度と $\mathrm{Ca}^{2+}$ 流入量の 増加の抑制という心筋細胞内の環境变化で従来説明 されていた ${ }^{35)}$. しかし今回の検討は心筋細胞内での 薬理学的効果に加えて, $\beta$ 遮断剂が運動後の低 $\mathrm{K}^{+}$ 血症 (postexercise hypokalemia)を軽減することも $\beta$ 遮断剤の心臓突然死予防効果のひとつの機序にな りうることを示唆している.

\section{$\mathrm{VI}$.まと め}

右室流出路起源のPVCはその発生機序や運動誘発 性において交感神経との関連が常に問題となる．少 数例でのケーススタディではあるが，今回の検討か らこれらの関係を解く鍵のひとつに血清 $\mathrm{K}+$ 濃度が運 動前後で急激に変化することの重要性が指摘される.

追記：貴重な助言を頂きました九州大学健康科学セ ンターの大柿哲朗教授に深謝致します。本稿の一部 は総務省郵政事業庁高度医療研究の補助によった。

\section{〔文献〕}

1) Jouven X, Zureik M, Desnos M, Courbon D, Ducimetiere P : Long-term outcome in asymptomatic men with exercise-induced premature ventricular depolarizations. N Engl J Med, $2000 ; 343: 826 \sim 833$

2 ) Holt PM, Wainwright RJ, Curry PVL : Right ventricular outflow tract tachycardia in patients without apparent structural heart disease. Int J Cardiol, $1986 ; 10$ : 99 110

3 ) Proclemer A, Ciani R, Feruglio GA : Right ventricular tachycardia with left bundle branch block and inferior axis morphology : clinical and arrhythmological characteristics in 15 patients. PACE, $1989 ; 12: 977 \sim$ 989

4 ) Goy JJ, Tauxe F, Fromer M, Schlapfer J, Vogt P, Kappenberger L : Ten-years follow-up of 20 patients with idiopathic ventricular tachycardia. PACE, $1990 ; 13$ : $1142 \sim 1147$

5 ) Gill JS, Mehta D, Ward DE, Camm AJ : Efficacy of flecainide, sotalol, and verapamil in the treatment of right ventricular tachycardia in patients without overt cardiac abnormality. Br Heart J, $1992 ; 68$ : 392 397

6 ) Lerman BB, Belardinelli L, West GA, Berne RM, DiMarco JP : Adenosine-sensitive ventricular tachycardia : evidence suggesting cyclic AMP-mediated triggered activity. Circulation, $1986 ; 74: 270 \sim 280$

7 ) Ritchie AH, Kerr CR, Qi A, Yeung-Lai-Wah JA : Nonsustained ventricular tachycardia arising from the right ventricular outflow tract. Am J Cardiol, 1989 ; 64 : $594 \sim 598$

8 ) Wu D, Kou HC, Hung JS : Exercise-triggered paroxysmal ventricular tachycardia. A repetitive rhythmic activity possibly related to afterdepolarization. Ann Intern Med, 1981 ; 95 : 410 414

9 ）金谷庄藏，藤野武彦，小宮秀一，大柿哲朗，小室史恵, 加治良一, 山口恭子, 熊谷秋三: 定量的漸増運動負荷中 および回復期における血中カテコールアミン・血清カリウ ム・脂質および血糖の動態. 健康科学, $1986 ； 8: 35 \sim 41$

10）山口恭子, 藤野武彦，加治良一，金谷庄藏，大柿哲朗， 小室史恵, 満園良一：LTレベルでの長時間運動負荷に よる血液生化学動態 : 血清電解質, 醅素の変化とカテコ ラミンとの関係. 健康科学, $1987 ; 9: 117 \sim 123$

11）江島準一，加治良一，金谷庄藏，津田泰夫，大柿哲朗， 藤野武彦：自転車エルゴメーター運動負荷時および水泳 時における血液生化学動態の比較および $\alpha$ ブロッカーの 効果. 健康科学, $1990 ； 12 ： 115 \sim 119$

12）大庭百合賀，下池英明，久間文明，小池明広，金谷英樹, 柳 統仁, 大塚祥司, 大西 康, 植田典浩, 野崎雅彦, 丸 山 徹, 加治良一, 金谷庄藏, 藤野武彦, 仁保喜之: 木 ルター心電図からみた右室流出路起源の心室性不整脈の 発生機序の検討。心電図, $1999 ； 19 ： 344 \sim 350$

13）丸山 徹, 下池英明, 植田典浩, 加治良一, 金谷庄藏, 藤野武彦, 仁保喜之：心室性期外収縮と心拍数の相関関 係におよほす心室性期外収縮の発生部位の影響. 心電図, $1999 ; 19$ (suppl 1): 33

14) Shimoike E, Ueda N, Maruyama T, Kaji $Y$, Kanaya $S$, Fujino T, Niho $Y$ : Circadian rhythm of idiopathic ventricular arrhythmia originating from right and left ventricular outflow tract (abst). PACE, $2001 ; 24: 674$

15）金谷庄藏，藤野武彦，上園慶子，川崎晃一，森田ケイ， 宇都宮弘子, 青木理恵, 杉 真弓, 岩村初代, 大柿哲 朗：健康な学生にみられる不整脈の研究：心室性期外収 
縮と心拍数との関係. 健康科学, $1989 ； 11 ： 129 \sim 132$

16）金谷英樹, 吉村大輔, 小池明広, 久間文明, 下池英明, 柳 統仁, 大西 康, 植田典浩, 野崎雅彦, 丸山 徹, 加 治良一, 金谷庄藏, 藤野武彦, 仁保喜之, 津田泰夫 : 右 室流出路起源特発性心室性期外収縮により心室細動をき たした一例. 心臓, 1999；31(supp14)：72〜77

17）鎌倉史郎, 片山克彦, 岡野嘉明, 清水 涉, 須山和弘, 栗田隆志, 相原直彦, 下村克朗：体表面心電図による右 室起源特発性心室頻拍の発生部位の推定法. 心電図, $1996 ; 16: 174 \sim 184$

18) Winkle RA : The relationship between ventricular ectopic beat frequency and heart rate. Circulation, 1982 ; $66: 439 \sim 446$

19) Ito M, Maeda $Y$, Arita M, Ito S, Saikawa T, Omura I, Fujino T, Fukumoto T, Kikuchi Y, Yamada K, Yanaga $\mathrm{T}$ : Effects of oral diltiazem on ventricular premature contractions. J Electrocardiol, $1986 ; 19: 59 \sim 66$

20) Ito M, Tsumabuki S, Maeda $Y$, Arita M, Saikawa T, Ito S, Fujino T, Fukumoto T, Yamada K, Kikuchi Y : Suppression of ventricular premature contractions possibly related to triggered activity by oral diltiazem and atenolol. Jpn Circ J, 1987 ; $51: 217 \sim 229$

21) Vincent HH, Boomsma F, Man in't Veld AJ, Derkx FHM, Wenting GJ, Schalekamp MADH : Effects of selective and nonselective $\beta$-agonists on plasma potassium and norepinephrine. J Cardiovasc Pharmacol, $1984 ; 6: 107 \sim 114$

22) Akaike $\mathrm{N}$ : Sodium pump in skeletal muscle : central nervous system-induced suppressoin by $\alpha$-adrenoreceptors. Science, $1981 ; 213: 1252 \sim 1254$

23) Akaike N, Hirata A, Kiyohara T, Oyama Y : Neural regulation on the active sodium-potassium transport in hypokalaemic rat skeletal muscles. J Physiol (Lond), 1983 ; $341: 245 \sim 255$

24) Williams ME, Gervino EV, Rosa RM, Landsberg L, Young JB, Silva P, Epstein FH : Catecholamine modulation of rapid potassium shifts during exercise. $\mathrm{N}$ Engl J Med, 1985 ; $312: 823 \sim 827$
25) Brown MJ, Brown DC, Murphy MB : Hypokalemia from beta $_{2}$-receptor stimulation by circulating epinephrine. $\mathrm{N}$ Engl J Med, 1983 ; 309 : 1414 1419

26) Langer GA : The 'sodium pump lag' revisited. J Mol Cell Cardiol, $1983 ; 15: 647 \sim 651$

27) Aronson RS : Delayed afterdepolarizations and pathological states. In Cardiac Electrophysiology, ed by Rosen MR, Janse MJ, Wit AL, Futura, New York, 1990 ; $303 \sim 322$

28) Kobayashi Y, Miyata A, Tanno K, Kikushima S, Baba T, Katagiri $\mathrm{T}$ : The effects of nicorandil, a potassium channel opener, on idiopathic ventricular tachycardia. J Am Coll Cardiol, $1998 ; 32: 1377 \sim 1383$

29) Kléber AG : Sodium-potassium pumping. In Cardiac Electrophysiology, ed by Rosen MR, Janse MJ, Wit AL, Futura, New York, $1990 ; 37 \sim 54$

30) Coetzee WA, Opie LH : Effects of components of ischemia and metabolic inhibition on delayed afterdepolarizations in guinea pig papillary muscle. Circ Res, 1987 ; $61: 157 \sim 165$

31) BHAT Study Group : A randomized trial of propranolol in patients with acute myocardial infarction : mortality results. JAMA, $1982 ; 247: 1707 \sim 1714$

32) Packer M, Bristow MR, Cohn JN, Colucci WS, Fowler MB, Gilbert EM, Shusterman NH : The effect of carvedilol on morbidity and mortality in patients with chronic heart failure. US Carvedilol Heart Failure Study Group. N Engl J Med, 1996 ; 334 : 1349 1355

33) CIBIS- II Investigators and Committees : The cardiac insufficiency bisoprolol study II: a randomized trial. Lancet, 1999 ; $353: 9 \sim 13$

34) MERIT-HF Study Group : Effect of metoprolol CR/XL in chronic heart failure : metoprolol $\mathrm{CR} / \mathrm{XL}$ randomized intervention trial in congestive heart failure. Lancet, 1999 ; 353 : 2001 2007

35) Opie LH, Yusuf S : Beta-blocking agents. In Drugs for the Heart, ed by Opie LH, Gersh BJ, Saunders, Philadelphia, $2001 ; 1 \sim 32$ 